\title{
HABLUNMINANNAS WANITA BERCADAR (STUDI FENOMENOLOGI INTERAKSI SOSIAL WANITA BERCADAR DI KECAMATAN MANGGALA MAKASSAR)
}

\section{Habluminannas of Women Wearing Veil (Phenomenology Study on the Construction of Social Interaction of Women Wearing Veil in Manggala Makassar City)}

\section{Fauziah Ramdani}

Sekolah Tinggi Ilmu Islam dan Bahasa Arab (STIBA) Makassar Email: fauziah_ramdani@stiba.ac.id

\author{
Aswar \\ Sekolah Tinggi Ilmu Islam dan Bahasa Arab (STIBA) Makassar \\ Email: aswar@stiba.ac.id
} Keywords :
Phenomenology. Social Interaction.
Veil

\begin{abstract}
Cultural identity of women with veil in the concept of the development of relationship with social ernironment perpetually becomes pros-and-cons phenomenon due to its accordance with the comprehension of religious symbols that is the wering of veil. The objectives were to recognize and describe the empirical reality of habluminannas concept that is the process of social interaction of women with veil. To comprehensively and deeply achieve these objectives, the methodology employed was descriptive qualitative research with in-depth interviews and observations (field research) as data collection techniques. The results show that the concept of habluminannas, that is social interaction of women with veil, is based on the essence of each need in daily social life. The process of interacting with other individuals both within the family and people in general depends on the interests and needs of each. Social interaction within the family is divided into two those are interaction that shows flexibility in communication and behavior patterns, and interaction that is closed and bounded. In the community, the process of social interaction that is associative process shows the flexibility of women with veil in the patterns of cooperation among citizens and relatives, mutual respect, and respect for the values of decency and politeness. On the other hand, the attitude of acceptance by community in general towards women wearing veil is still not prevalent due to the negative stigma against the use of veils. ABSTRAK

Identitas wanita bercadar dalam kaitannya dengan konsep hubungan dengan lingkungan sosial selalu menjadi fenomena pro dan kontra, karena kaitannya dengan simbol-simbo keagamaan seperti penggunaan cadar. Tujuan yang hendak dicapai adalah untuk mengetahui serta mendeskripsikan realitas dari konsep hablun minannas yaitu proses interaksi sosial wanita bercadar. Untuk mencapai tujuan tersebut secara menyeluruh dan mendalam maka metodologi yang digunakan adalah penelitian deskriptif kualitatif dengan teknik pengumpulan data depth interview (wawancara mendalam) dan observasi (penelitian lapangan). Hasil penelitian menunjukkan konsep hablun minannas yaitu interaksi sosial wanita bercadar berlandaskan pada esensi dari kebutuhan masingmasing dalam kehidupan sosial sehari-hari. Proses interaksi dengan individu lainnya baik dalam lingkup keluarga maupun masyarakat secara umum tergantung pada kepentingan dan kebutuhan masing-masing. Interaksi sosial atau hablun minannas dalam lingkup masyarakat secara umum terbagi atas dua kondisi yaitu; interaksi yang menunjukkan fleksibilitas dalam pola-pola tingkah laku serta interaksi yang bersifat terbatas. Di lingkup masyarakat, proses interaksi sosial wanita bercadar bersifat terbuka, yaitu wanita bercadar turut aktif terlibat dalam proses kerjasama antar masyarakat dan menunjukkan sikap saling menghargai dan menghormati antar individu dalam masyarakat. Di lain sisi, wanita bercadar terkesan dianggap sebagai wanita eksklusif yang belum bisa berbaur dengan masyarakat dengan komunikasi dan interaksi sosial.
\end{abstract} ABSTRACT

Kata kunci :

Fenomenologi. Interaksi Sosial.

Diterima: 5 April 2020; Direvisi: 29 Mei 2020; Disetujui: 29 Mei 2020; Tersedia online: 12 Juni 2020.

How to cite : Ramdani, F., Aswar. (2020). Hablun Minannas Wanita Bercadar (Studi Fenomenologi Interaksi Sosial Wanita Bercadar di Kecamatan Manggala Makassar). NUKHBATUL 'ULUM: Jurnal Bidang Kajian Islam, 6 (1), 105-121. https://doi.org/10.36701/nukhbah.v6i1.114

Fauziah Ramdani., Aswar. Hablun Minanas Wanita... 


\section{PENDAHULUAN}

Konsep fundamental yang menjadi landasan kehidupan di dalam perpesktif Islam, yaitu hablun minallah dan hablun minannas ini mengajarkan tentang makna dan nilai-nilai yang terkandung dari hubungan yang terbangun ke dalam dua arah, yakni secara vertikal/ transendental; manusia dengan Penciptanya. Serta konsep hubungan secara horizontal yaitu manusia dengan manusia lainnya. Allah 'Azza wa Jalla berfirman:

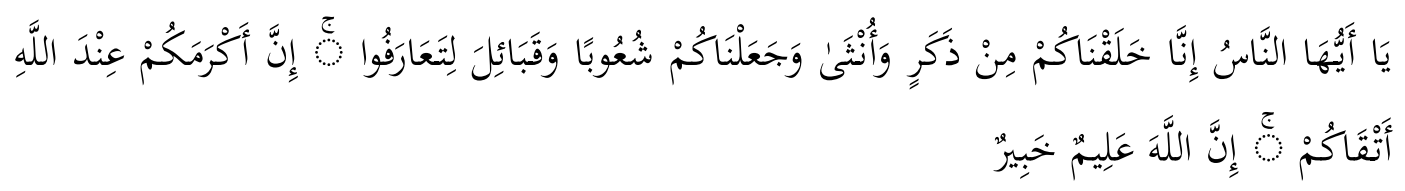

Terjemahan: "Hai manusia, sesungguhnya Kami menjadikan kamu dari seorang laki-laki dan seorang wanita, dan menjadikan kamu berbangsa-bangsa dan bersuku-suku supaya saling mengenal. Sesungguhnya orang mulia di antara kamu di sisi Allah adalah orang yang paling bertakwa. Sesungguhnya Allah Maha Mengetahui Lagi Maha Mengenal."'

Hubungan kepada sesama manusia itulah yang dalam konsepsi Islam disebut dengan istilah hablun minannas sedangkan dalam istilah sosiologi dikenal dengan istilah interaksi sosial. Terjemahan ayat tersebut di atas menjadi dasar atas pengejawantahan ekspresi dari eksistensi konsep interaksi sosial antar sesama manusia yang idealnya harus terpelihara dalam kehidupan bermasyarakat, dimana sebelumnya telah dijelaskan bahwa yang dimaksud dengan interaksi adalah aksi timbal balik, saling mengenal dan saling berinteraksi antar satu sama lain.

Sebagaimana suatu sistem hubungan sosial antar manusia, fenomena hablun minannas ini memiliki kadar (ukuran) dan nilai yang berbeda-beda serta biasanya hal tersebut dilatarbelakangi oleh adanya perbedaan kondisi lingkungan keluarga (kerabat), adat-istiadat dan sosial budaya masing-masing individu. Hal itu pula yang terjadi pada suatu komunitas yang eksistensinya selalu disebut 'berbeda' dari masyarakat secara umum. Yaitu wanita bercadar, sebuah konsep diri yang disematkan bagi perempuan yang mengenakan penutup wajah.

Wanita bercadar adalah wanita muslimah yang mengenakan baju panjang sejenis jubah dan menutup semua badan hingga kepalanya serta memakai penutup muka

\footnotetext{
${ }^{1}$ Al-Qur'an, Al-Hujurat/49: 13.
} 
atau cadar sehingga yang nampak hanya kedua matanya. ${ }^{2}$ Penggunaan cadar menambah penutup wajah, sehingga hanya terlihat mata saja, bahkan telapak tangan pun harus ditutupi dan juga berjilbab mensyaratkan pula penggunaan baju panjang. Maka bercadar diikuti pula penggunaan gamis (bukan celana), rok-rok panjang dan lebar dan biasanya seluruh aksesoris berwarna hitam gelap. ${ }^{3}$

Dalam perkembangannya, cara-cara berpakaian yang diekspresikan oleh wanita bercadar yang serba tertutup itu, tidak sedikit menimbulkan stigmatisasi dan streotipe negatif secara psikologis dan sosiologis (interaksi sosial) yaitu sikap yang terkesan eksklusif dan kaku.

Cadar atau hijab merupakan salah satu indikator wanita dewasa awal dan memiliki nilai religiusitas. Religiusitas dan agama memang merupakan satu kesatuan yang tidak bisa dipisahkan dalam penggunaan cadar. Agama dan religiusitas saling mendukung dan saling melengkapi karena keduanya merupakan konsekuensi logis dari kehidupan manusia yang mempunyai dua kutub, yaitu kutub kehidupan pribadi dan kutub kebersamaannya di tengah masyarakat. $^{4}$

Hasil penelitian yang dilakukan terhadap wanita bercadar di Surakarta Jawa Timur, ditemukan beberapa hal penting seperti konsep dan sikap diri yang membatasi cara berpikir perempuan bercadar menjadi terbatas dan terbelenggu dengan dalih sesuai syariat. Hal-hal tersebut terjadi antara lain karena pengalaman subjektif wanita bercadar, sudut pandang, prasangka, prinsip hidup, kepentingan, referensi pembanding, dan pemikiran-pemikiran keagamaan yang berkembang dalam komunitas, atau tempat perempuan bercadar itu bersosialisasi dan atau berdomisili. ${ }^{5}$

Fenomena wanita bercadar menjadi suatu hal yang sudah tidak asing lagi untuk ditemui. Seperti yang dilansir dalam salah satu artikel pada website kompasiana yang menyebutkan bahwa jika dicermati dengan seksama jumlah pemakai cadar di seluruh Indonesia mengalami kenaikan yang sangat fantastis. Di berbagai daerah seperti Bandung, Jakarta, Aceh, Poso, Makasar, dan Pekanbaru. Begitu banyaknya dapat dikatakan bahwa keberadaan wanita bercadar telah menyebar di

\footnotetext{
${ }^{2}$ Taimiyah, dkk. Hijab dan Cadar bagi Wanita Muslimah. (Yogyakarta: At Tuqa, 2010), h. 45 .

${ }^{3}$ Ratri, L. "Cadar, Media, dan Identitas Perempuan Muslim.” In Forum 39, No. 2 (2011): h. 29-37.

${ }^{4}$ Shihab, M. Qurais, Membumikan Al-Qur'an, Fungsi dan Peran Wahyu dalam. Masyarakat, (Bandung: Mizan Media Utama, 2010) h. 58.

${ }^{5}$ Ghonimah, G, "Identitas Mahasiswi Berrcadar Di Universitas Islam Negeri Sunan Ampel Surabaya”, Doctoral dissertation, (Surabaya: UIN Sunan Ampel Surabaya, 2017).
} 
seluruh kota di Indonesia. Hal ini tidak terlepas dari konsep dakwah ajaran yang telah menyebar ke seluruh pelosok tanah air. ${ }^{6}$ Prasetyo mengungkapkan bahwa perempuan bercadar lebih memilih rasionalisasi daripada proyeksi, sebagai cara untuk melepaskan diri dari pertentangan atau konflik batin. Salah satu contohnya adalah adanya konstruksi kesadaran tentang 'menghindari fitnah' sebagai motif penggunaan cadar. Hal tersebut menunjukkan bahwa perempuan bercadar cenderung membangun suatu penjelasan dan alasan-alasan personal, daripada meletakkan kesalahan pada pihak lain, dalam hal ini laki-laki sebagai lawan bergaul sehari-hari. ${ }^{7}$

Berbeda dengan Prasetyo yang mengkaji dan mencermati wanita bercadar dari sisi konsep citra diri mereka berdasarkan idealisme agama yang disesuaikan dengan realitas sosial. Penelitian ini fokus menindaklanjuti objek yang sama dengan sudut pandang yang berbeda dan menjadi kajian yang menarik tentang bagaimana konstruksi dari konsep hablun minannas atau interaksi sosial wanita bercadar dalam kehidupan bermasyarakatnya. Konsep sosial secara umum dengan praktek-praktek kesantunan seperti saling sapa, berjabat tangan, silaturrahim, solidaritas sosial, ukhuwah Islamiah dan lain-lain. Interaksi sosial (hablun minannas) tersebut tidak hanya terjadi dalam lingkup komunitas atau intra kelompoknya sesama wanita bercadar, akan tetapi juga diluar dari komunitasnya.

Hal tersebut menunjukkan relevansi teori agama dengan realitas sosial yang dilakonkan wanita bercadar dalam kehidupan sehari-hari. Dari latar belakang tersebut di atas, untuk mencapai penelitian yang terarah dan sistematis, maka fokus penelitian dibatasi sebagai berikut:

Bagaimana wanita bercadar menggambarkan pengalaman-pengalamannya dalam konstruksi interaksi sosial (hablun minannas) di dalam dan di luar dari komunitasnya?

Tujuan dari penelitian ini adalah untuk memperoleh sejumlah data dan informasi terhadap konstruksi interaksi sosial (hablun minannas) wanita bercadar dalam kehidupan sehari-hari. Olehnya itu, guna menjawab beberapa permasalahan sebagaimana yang telah dirumuskan di atas, maka tujuan penelitian ini yaitu:

${ }^{6}$ Jumaidah, J, "Problematika pemakaian cadar di Universitas Islam Negeri (UIN) Walisongo Semarang”, Doctoral dissertation, (Semarang: UIN Walisongo Semarang, 2018).

Prasetyo, "Pengertian Cadar" dalam http://repository.uma.ac.id/bitstream/123456789/2052/5/128600060_file5.pdf/ diakses pada 1 Mei 2019. 
1. Untuk mendeskripsikan gambaran interaksi social (hablun minannas) wanita bercadar;

2. Untuk mengetahui dan menggambarkan pengalaman-pengalaman dalam konstruksi interaksi sosial (hablun minannas) di dalam dan di luar dari komunitas wanita bercadar dalam kehidupan sehari-hari.

Secara spesifik, penelitian ini bertujuan untuk mengetahui, memahami, menggambarkan dan menganalisis konsep interaksi sosial (hablun minannas) wanita bercadar di Kecamatan Manggala Kota Makassar dalam kehidupan sehari-hari.

\section{METODE}

Metodologi penelitian yang digunakan adalah deskriptif kualitatif dengan teknik pengumpulan data depth interview (wawancara mendalam) dan observasi (penelitian lapangan). Ihwal observasi lapangan dan depth interview adalah dua hal yang saling sejalan dengan partisipasi peneliti dalam penelitian lapangan (khususnya pada subjek manusia), bahkan dapat dikatakan bahwa depth interview adalah bagian dari observasi itu sendiri. ${ }^{8}$ Guna memperoleh uraian yang jelas tentang konsep interaksi sosial (hablun minannas) wanita bercadar, maka tipe riset fenomenologi empiris diterapkan pada penelitian ini. Fenomenologi empiris dimaksudkan sebagai dasar prosedur ilmiah dalam menggali data subjek terteliti yang fokus pada pengalaman hidup individu dan perhatiannya terhadap intensionalitas interaksi manusia dalam lingkungan dimana dia hidup/eksis. ${ }^{9}$

\section{PEMBAHASAN}

\section{Persepsi Tentang Cadar}

Dewasa ini dapat kita saksikan banyak wanita yang telah mengenakan jilbab di tempat-tempat umum baik yang berjubah, berbaju kurung atau celana. Ini tentu saja merupakan fenomena yang baik jika dibandingkan dengan zaman terdahulu

${ }^{8}$ Mappiare, A., Dasar-dasar Metodologi Riset Kualitatif Untuk Ilmu Sosial dan Profesi, (Malang: Jenggala Pustaka Utama Bersama Fakultas Ilmu Pendidikan Universitas Negeri Malang, 2009), h. 114.

${ }^{9}$ Mappiare, A., Tipe-tipe Metode Riset Kualitatif Untuk Eksplanasi Sosial Budaya dan Bimbingan Konseling, (Malang: Elang Mas bersama Prodi Bimbingan dan Konseling Fakultas Ilmu Pendidikan Universitas Negeri Malang, 2013), h. 78. 
dimana masih sangat jarang terlihat wanita yang mengenakan jilbab terlebih lagi menggunakan cadar (penutup wajah).

Cadar merupakan versi lanjutan dari jilbab. Pengguna cadar menambahkan penutup wajah sehingga hanya terlihat mata mereka saja, bahkan telapak tangan pun harus ditutupi. Jika berjilbab mensyaratkan pula penggunaan baju panjang, maka bercadar diikuti kebiasaan penggunaan gamis (bukan celana), rok-rok panjang dan lebar, dan biasanya seluruh aksesoris berwarna hitam atau berwarna gelap. Namun, jika jilbab bisa masuk ke dalam budaya lokal, maka cadar belum mampu menembus media massa, tempat produksi budaya-budaya populer. Justru sampai saat ini, media menampilkan cadar sebagai bagian dari indikator identitas istri teroris. Pandangan media inilah yang mendominasi cara pandang masyarakat terhadap cadar. Pada proses itulah cadar belum sepenuhnya diterima oleh masyarakat Indonesia secara umum, karena pemahaman akan cadar masih berjarak dengan budaya setempat. Cadar masih dianggap sebagai barang asing yang menakutkan. Hal ini didukung stigmatisasi yang ditayangkan oleh media di antaranya 'istri teroris', 'Islam garis keras', 'Islam fanatik'. ${ }^{10}$

Di Indonesia sendiri, era 1980an jilbab bak jamur di musim hujan, mulai tumbuh subur dimana-mana, seiring dengan derasnya kebangkitan pelajar di kampus yang tampil sebagai pergerakan keagamaan. Fenomena ini mempunyai identitas yang serupa dihampir keseluruhan negeri-negeri Islam. Jilbab menghiasi dunia kampus dan masyarakat kota. Diawali di kampus-kampus umum; seperti ITB, IPB, UGM, UII dan kampus-kampus lainnya, termasuk kemudian menjadi tren di kalangan luas. Jelas ini adalah pemandangan yang luar biasa dan perubahan yang signifikan, tidak seperti pada dekade sebelumnya. ${ }^{11}$

Fenomena wanita bercadar beberapa tahun terakhir ini tidak sedikit mengikis stigmatisasi negatif yang berkembang bahwasanya cadar dipandang sebagai simbol-simbol keagamaan yang cenderung mudah bersikap ekstrim dan fanatik terhadap dogma keagamaan. Kendati demikian, semakin tingginya rasa ingin tahu masyarakat terhadap konsep cadar yang juga diikuti dengan meningkatnya kuantitas jumlah pemakai cadar di kalangan muslimah. ${ }^{12}$ Sebagaimana hasil wawancara berikut:

\footnotetext{
${ }^{10}$ Ratri, L, "Cadar, Media, dan Identitas Perempuan Muslim." In Forum 39, No. 2 (2011): h. 29-37.

${ }^{11}$ Fathonah K. Daud. Jilbab, "Hijab dan Aurat Perempuan: Antara Tafsir Klasik , Tafsir Kontemporer dan Pandangaan Muslim Feminis.” Al Hikmah: Jurnal Studi Keislaman 3, No. 1, (2013): h.3.

${ }^{12}$ Rahman, A. F., \& Syafiq, M, "Motivasi, stigma dan coping stigma pada perempuan bercadar." Jurnal Psikologi Teori dan Terapan, 7, No.2, (2017): h. 103-115.
} 
"Saya memakai cadar sejak tahun 2005, karena kewajiban seorang muslim menutup aurat, yang saya tahu bahwa semakin mulia perempuan jika dijaga dengan memakai cadar. Kenapa saya memakai cadar, jadi waktu itu ketika saya kuliah, saya mulai merasa risih dilingkungan kampus, banyak teman laki-laki, dan saya ingin menjaga diri, salah satunya dengan memakai cadar. $^{\text {’13 }}$

Salah satu alasan yang mendorong wanita menggunakan cadar adalah agar terhindar dari fitnah, atau gangguan dari laki-laki. Sifat malu yang merupakan ciri khas perempuan jelas tergambarkan dari penjelasan informan. Sikap kehatihatian yang besar terhadap eksistensi dirinya dalam kehidupan bermasyarakat agar tidak menjadi 'peluang fitnah' merupakan potensi kuat yang menggerakkan wanita tersebut menggunakan cadar.

Selain itu, karena faktor keilmuan yang telah diperoleh melalui kajian keislaman dan membaca buku seputar cadar adalah menjadi alasan mengapa kuantitas wanita bercadar semakin meningkat. Sebagaimana yang disampaikan oleh informan berikut:

"Saya memakai cadar dari semester lima, dan saya memakai cadar.. alasannya sebenarnya banyak, tetapi yang paling mendominasi adalah karena berbeda tipis antara hukum memakai cadar yang wajib dan sunah, dan banyaknya pendapat ulama yang menyatakan wajib, selain itu juga karena ingin menjaga diri. ${ }^{\text {} 4}$

Cadar dalam Kamus Besar Bahasa Indonesia (KBBI) berarti kain penutup kepala atau muka (bagi perempuan). Dalam bahasa Arab cadar disebut dengan نِقuاب, niqoob bentuk jamaknya nuquub. Dalam kamus Al-Munawwir niqoob (penutup wajah) berarti kain tutup muka. Dalam kamus Lisaanul Arab (kamus besar bahasa Arab karya al Allamah al Lughawiy) kata niqoob (penutup wajah) yaitu kain penutup wajah bagi perempuan hingga hanya kedua mata saja yang terlihat. Dari arti kata cadar di atas, dapat dipahami bahwa cadar adalah suatu nama yang diperuntukkan bagi pakaian yang berfungsi untuk menutup wajah bagi perempuan. Wanita bercadar adalah wanita muslimah yang mengenakan baju panjang sejenis jubah dan menutup semua badan hingga kepalanya serta memakai penut up muka atau cadar sehingga yang tampak hanya kedua matanya. ${ }^{15}$

\footnotetext{
${ }^{13}$ Hasil wawancara informan I, ( wawancara dilaksanakan pada 1 Mei 2019).

${ }^{14}$ Hasil wawancara informan I, ( wawancara dilaksanakan pada 1 Mei 2019)

${ }^{15}$ Taimiyah, dkk., Hijab dan Cadar bagi Wanita Muslimah, (Yogyakarta: At Tuqa,
} 2010), h. 66 . 
Cadar dalam Islam adalah jilbab yang tebal dan longgar yang menutup semua aurat termasuk wajah dan telapak tangan. Dasar dari penggunaan cadar adalah untuk menjaga perempuan sehingga tidak menjadi fitnah dan menarik perhatian laki-laki yang bukan mahramnya. Penggunaan cadar menambah penutup wajah, sehingga hanya terlihat mata saja, bahkan telapak tangan pun harus ditutupi, jika berjilbab mensyaratkan pula penggunaan baju panjang. ${ }^{16}$

Adapun bercadar diikuti pula penggunaan gamis (bukan celana), rok-rok panjang dan lebar dan biasanya seluruh aksesoris berwarna hitam gelap. ${ }^{17}$ Dalam sejarahnya, bahwa cadar (chadar dalam bahasa Persia berarti tenda) telah dikenakan oleh perempuan-perempuan bangsawan di tempat-tempat umum sejak dinasti Hakhamanesh. Kemudian diikuti oleh beberapa tradisi kerajaan di bawah kerajaan Persia pada tahun 500 SM. ${ }^{18}$

Memakai cadar bagi seorang muslimah bukanlah perkara yang mudah, tentu saja selain keilmuan yang harus dimiliki sebagai landasan awal untuk mengkonstruksi penampilan diri dengan sesuatu yang berbeda juga dibutuhkan keberanian untuk tampil di depan publik. Sebab polemik persoalan pemakaian cadar di antaranya karena hukum cadar itu sendiri yang masih diperdebatkan tentang wajib atau tidaknya. Sebagaimana informasi informan sebagai berikut:

"Kalau saya tidak ada secara spesifik orang tertentu yang memotivasi saya untuk bercadar, tentu selain karena alasan ilmu. Akan tetapi, ada beberapa kejadian yang secara beruntun terjadi sama saya, misalnya saat mau magang di kantor, saya melihat ada seorang akhawat yang lagi makan dalam keadaan bercadar, saya sangat respek, selain itu, juga karena banyak kisah dari beberapa orang akhawat tentang perjuangannya mempertahankan cadarnya. "19

Dalam mencermati hubungan antara perempuan muslimah dengan pemakaian cadar, terdapat beberapa pendapat tentang cadar. Salah satunya adalah mereka yang mengatakan bahwa jilbab merupakan suatu kewajiban yang harus dilaksanakan oleh setiap perempuan muslimah yang sudah balig.

\footnotetext{
${ }^{16}$ Shihab, M. Quraish, Jilbab: Pakaian Wanita Muslimah (Pandangan Ulama Masa Lalu dan Cendekiawan Kontemporer), (Jakarta: Lentera Hati, 2014), h. 129

${ }^{17}$ Ratri, L, "Cadar, Media, dan Identitas Perempuan Muslim.” In Forum 39, No. 2 (2011): h. 29-37.

${ }^{18}$ Rudianto, “Jilbab sebagai Kreasi Budaya (Studi Kritis Ayat - ayat Jilbab dalam AlQur'an, (Medan: IAIN PRESS, 2006), h. 39.

${ }^{19}$ Hasil wawancara informan I, ( wawancara dilaksanakan pada 1 Mei 2019
} 
Berdasarkan pendapat ini, perempuan muslimah diwajibkan untuk berjilbab sekaligus menutup wajahnya dengan cadar, oleh karena didasarkan pada firman Allah 'Azza wa Jalla:

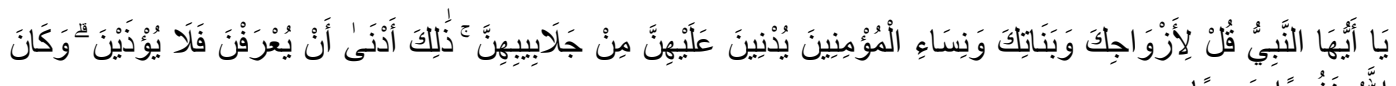

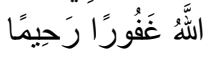

Terjemahan: "Wahai Nabi! Ucapkanlah kepada istri-istrimu, katakan kepada anak-anak perempuanmu dan katakan kepada istri-istri kaum mukminin, agar mereka memanjangkan jilbab yang mereka pakai ke seluruh tubuh mereka sehingga aurat mereka tidak tersingkap dihadapan lelaki asing. Yang demikian ini agar mereka lebih mudah dikenali sebagai orang merdeka, sehingga tidak ada orang yang mengganggu mereka sebagaimana gangguan yang biasa dialami oleh hamba sahaya perempuan. Dan Allah Maha Pengampun atas dosa-dosa para hamba-Nya yang bertobat kepada-Nya, lagi Maha Penyayang kepada mereka. ${ }^{\text {,20 }}$

Berbagai macam argumen dikeluarkan untuk mendukung dan berbagai kontroversi pandangan tentang cadar juga banyak dilontarkan. Ada yang mewajibkan, menyunahkan dan memubahkan pemakaiannya.

Fenomena pemakaian cadar sebagai salah satu implementasi syariat Islam tidak sedikit menimbulkan pro dan kontra di kalangan masyarakat umum. Informan mengatakan bahwa:

"Tanggapan saya tentang fenomena wanita bercadar saat ini kalau menurut saya ini bisa dilihat dari dua sisi negatif dan positif. Ada sebagian yang menggunakan cadar hanya sebagai tren saja, model berhijab, akan tetapi ada juga dan semoga ini yang lebih banyak di kalangan muslimah yang insyaa Allah niatnya untuk menyempurnakan hijab dengan bercadar karena adanya ilmu. Selain itu, kalau kita melihat hari ini, sebagian masih ada yang merasa asing dengan penggunaan cadar, tetapi di era sekarang ini sudah banyak yang merasa enjoy dengan ramainya muslimah yang memakai cadar. ${ }^{\text {,21 }}$

Realitasnya, nilai-nilai normatif yang berasaskan konsepsi ketuhanan ini belum bisa diterima di seluruh lapisan masyarakat. Sebagaimana hasil wawancara berikut:

\footnotetext{
${ }^{20}$ Al-Qur'an, Al-Ahzab/33: 59.

${ }^{21}$ Hasil wawancara informan II, ( wawancara dilaksanakan pada 1 mei 2019).
} 
"Awal mula memakai cadar tentu saja tidak mudah, apalagi di kampus, ada beberapa kalangan dosen yang tidak suka, menyindir dan kurang respek dengan akhawat bercadar, karena mereka menganggap tertutup dan mereka menganggap kami eksklusif, padahal sebenarnya kami hanya ingin menjaga pergaulan saja agar bisa meminimalkan ikhtilat, tidak ada maksud yang lain. ${ }^{, 22}$

Adanya pemahaman yang berkembang dan beranggapan bahwa perempuan yang memakai cadar itu hanya kedok belaka, mereka beranggapan bahwa perempuan yang memakai cadar adalah teroris atau penganut aliran sesat. Ada pula sebagian masyarakat yang beranggapan bahwa perempuan bercadar tidak mau bersosialisasi dengan masyarakat lainnya, bahkan ada masyarakat yang menganggap cadar hanya alat untuk menutup-nutupi kejelekan (kekurangan) fisik. Sebagaimana hasil wawancara berikut:

"Kesulitan disaat awal-awal pakai cadar cukup banyak, tantangan dari keluarga yang tidak mendukung, merasa bahwa cadar hanya sekadar menutupi kekurangan fisik. Yah selain itu ragu-ragu apakah nanti menikah, bagaimana pekerjaannya dan kekhawatiran lainnya. Tetapi seiring waktu, kami tunjukkan bahwa dengan cadar kami juga bisa berprestasi, mereka akhirnya Alhamdulillah merespon baik. ${ }^{2} 3$

Padahal tidak demikian yang terjadi pada sebagian perempuan muslimah bercadar, mereka mampu menunjukkan interaksi sosial terhadap masyarakat sekitar. Sebagaimana hasil wawancara berikut:

"Yang berubah setelah memakai cadar, kalau saya pribadi tidak ada, kecuali memang ada batasan-batasan yang perlu diperhatikan dalam berinteraksi dengan laki-laki. Akan tetapi, kalau yang lain, saya merasa sama saja. Tetap berinteraksi dengan baik dan alhamdulillah saya mudah bergaul dengan orang lain. Tidak ada yang sulit. Di lingkungan keluarga yang saya lakukan adalah berupaya untuk selalu menampilkan yang terbaik, apalagi keluarga saya khususnya orangtua belum mendukung saya memakai cadar secara penuh. Otomatis hal yang utama adalah itu tadi, memperbaiki hubungan kepada keluarga agar tetap harmonis. ${ }^{\text {,2 }}$

\section{Interaksi Sosial Wanita Bercadar}

\footnotetext{
${ }^{22}$ Hasil wawancara informan III, (wawancara dilaksanakan pada 1 Mei 2019).

${ }^{23}$ Hasil wawancara informan III, (wawancara dilaksanakan pada 1 Mei 2019).

${ }^{24}$ Hasil wawancara informan II, (wawancara dilaksanakan pada 1 mei 2019).
} 
Interaksi sosial (hablun minannas) merupakan kunci semua kehidupan sosial. Dengan tidak adanya komunikasi atau interaksi antar satu sama lain, maka tidak ada kehidupan bersama. ${ }^{25}$ Kehidupan bermasyarakat yaitu interaksi sosial atau hablun minannas wanita bercadar menunjukkan pola yang beragam sebagaimana hasil wawancara berikut:

"Alhamdulillah saya mudah bergaul dengan orang lain. Tidak ada yang sulit. Di lingkungan keluarga yang saya lakukan adalah berupaya untuk selalu menampilkan yang terbaik, apalagi keluarga saya khususnya orang tua belum mendukung saya memakai cadar secara penuh. Otomatis hal yang utama adalah itu tadi, memperbaiki hubungan kepada keluarga agar tetap harmonis. $^{\text {,26 }}$

Proses interaksi sosial dalam kehidupan bermasyarakat terbagi atas dua proses yakni proses asosiatif dan proses disosiatif. Proses asosiatif dalam interaksi sosial adalah bentuk interaksi sosial yang dapat meningkatkan hubungan solidaritas antara individu meliputi bentuk-bentuk kerjasama (cooperation) dan akomodasi (accomodation) sebagai suatu proses yang menunjuk adanya suatu keseimbangan dalam interaksi di antara orang-orang, yang kaitannya dengan norma-norma sosial dan nilai-nilai sosial yang berlaku dalam masyarakat dan proses yang menunjuk pada usaha-usaha manusia untuk mencapai kestabilan. Sedangkan proses disosiatif merupakan bentuk interaksi sosial yang dapat merenggangkan hubungan solidaritas antar individu. Proses disosiatif meliputi persaingan, kontravensi, dan konflik. ${ }^{27}$ Sebagaimana hasil wawancara berikut:

"Tentu walau bercadar seperti sekarang ini, bergaul dengan lingkungan sekitar itu sangat penting, misalnya kita harus banyak-banyak menebar senyum kepada tetangga atau kepada teman. 'Awalnya kesulitan saat bercadar di keluarga, dalam proses interaksi Alhamdulillah lama kelamaan sudah lebih santai. Sebagai keluarga yang dasarnya memang awam, maka itu jelas adalah ujian kita, bagaimana kita mampu istikamah, itu yang tidak mudah dilakukan. Sebab banyak juga di kalangan akhawat yang saya dapati, girah-semangatnya untuk memakai cadar sangat besar sekali, saya punya teman seperti itu juga, ada teman yang memakai cadar bahkan sangat sempurna, akan tetapi karena tidak didukung oleh keluarga, ditentang maka tidak mampu untuk mempertahankan cadarnya, apalagi sama sekali belum 2012), h. 90 .

${ }^{25}$ Soerjono Soekanto, Sosiologi (Suatu Pengantar) (Jakarta: PT Raja Grafindo Persada,

${ }^{26}$ Hasil wawancara informan II, ( wawancara dilaksanakan pada 1 mei 2019).

${ }^{27}$ Zeitlin, Irving M, Memahami Kembali Sosiologi. (Yogyakarta: Gadjah Mada University Press, 1995), h. 29. 
tersentuh dakwah'. Juga biasanya kareena respon masyarakat yang kurang sreg dengan cadarnya. ${ }^{2} 8$

Eksklusivitas dan ketertutupan wanita bercadar juga merupakan bias penghambat proses sosialisasi dan interaksi sosial. Belum lagi masyarakat Indonesia yang serba ingin tahu, dari pola masyarakat kolektif, melihat hal-hal yang serba tertutup membuat mereka enggan untuk berinteraksi lebih jauh. Apa yang menjadi opini masyarakat adalah cadar belum menjadi budaya muslim Indonesia. Memerlukan studi lebih jauh dan intensif untuk mencapai kesadaran bercadar. Cadar masih menjadi milik komunitas tertentu yang mengkhususkan diri mempelajari agama Islam. ${ }^{29}$ Sebagaimana yang disampaikan oleh informan berikut:

"Saya merasa masih banyak yang beranggapan bahwa cadar ini adalah pakaian yang menunjukkan sikap fanatik terhadap agama dan mereka merasa orang-orang memakai cadar seperti saya ini tidak mampu bersosialisasi. Itulah mengapa masih banyak yang merasa tidak respek dengan wanita yang menggunakan cadar."30

Proses Interaksi sosial merupakan hubungan dinamis antara individu dengan individu, individu dengan kelompok dan kelompok dengan kelompok. Interaksi sosial dengan berbagai jenisnya seperti kerja sama, persaingan, pertikaian, tolong-menolong dan gotong-royong juga menjadi praktik nyata sekaligus memicu ketegangan social dalam kehidupan sosial wanita bercadar. Interaksi sosial yang dilakukan merupakan kunci dari seluruh kehidupan sosial, karena tanpa interaksi sosial tidak akan mungkin terjadi kehidupan bersama. Interaksi terjadi antara orang-perorangan, kelompok dengan kelompok, dan individu dengan kelompok. ${ }^{31}$

Wanita bercadar secara variatif menunjukkan sikap antusias dalam berinteraksi sosial, walaupun dengan konsep diri yaitu penampilan secara fisik yang berbeda yakni memakai cadar. Sebagaimana hasil wawancara berikut ini:

\footnotetext{
${ }^{28}$ Hasil wawancara informan II, ( wawancara dilaksanakan pada 1 mei 2019).

${ }^{29}$ Ratri, L, "Cadar, Media, dan Identitas Perempuan Muslim." In Forum 39, No. 2

${ }^{30}$ Hasil wawancara informan II, ( wawancara dilaksanakan pada 1 mei 2019).

${ }^{30}$ Zeitlin, Irving M, Memahami Kembali Sosiologi. (Yogyakarta: Gadjah Mada

${ }^{31}$ Soerjono Soekanto, Sosiologi (Suatu Pengantar) (Jakarta: PT Raja Grafindo Persada,
} (2011): h. 29-37. University Press, 1995), h. 29. 2012), h. 49. 
"Alhamdulillah saya mudah bergaul dengan orang lain. Tidak ada yang sulit. Di lingkungan keluarga yang saya lakukan adalah berupaya untuk selalu menampilkan yang terbaik, apalagi keluarga saya, khususnya orangtua belum mendukung saya memakai cadar secara penuh. Otomatis hal yang utama adalah itu tadi, memperbaiki hubungan kepada keluarga agar tetap harmonis. $^{\text {' } 2}$

Interaksi sosial wanita bercadar ditunjukkan dengan adanya sikap partisipasif terhadap masyarakat sekitarnya berbaur, menerima perbedaan-perbedaan stat us sosial dan persepsi tentang keagamaan. Begitupun juga dalam lingkup keluarga internal, wanita bercadar secara loyal menunjukkan sikap kepedulian. Sedangkan dalam lingkup akademik menunjukkan sikap yang variatif dalam menerima pakaian syar'i wanita bercadar yaitu dengan penggunaan cadar itu sendiri. Sebagaimana pernyataan informan berikut:

"Dikampus itu Alhamdulillah cadar tidak dilarang, memang penerimaan cadar tidak bisa merata di semua pihak, apalagi dosen, ada juga yang tidak pro dengan pemakaian cadar, maka kita harus bersabar dan siap dengan kondisi yang ada. ${ }^{33}$

Sikap masyarakat umum dalam menerima keberadaan wanita bercadar berbedabeda, sebagaimana yang dijelaskan oleh informan tersebut, ada yang menerima juga tidak sedikit yang menolak. Hal tersebut sudah menjadi konsekuensi pilihan hidup dari idealime yang dijunjung tinggi oleh wanita bercadar, dan mereka siap dengan segala problematika yang harup dihadapi saat memutuskan untuk menggunakan cadar. Sebagaimana yang dinyatakan oleh informan sebagai berikut:

"Alhamdulillah tidak ada kesulitan dalam berinteraksi selama bercadar, dan tidak ada yang perlu saya khawatirkan. Juga selain itu, perasaannya selama bercadar sangat nyaman, karena merasa ini adalah bagian dari ketaatan kepada Allah. Adapun secara umum sebenarnya banyak tanggapantanggapan misal tentang kenapa bercadar, jadi dijawab saja sesuai siapa yang bertanya. $^{34}$

Persepsi wanita bercadar, sebagai wanita yang kuno, eksklusif dan tidak pandai bergaul, berinteraksi dengan masyarakat secara umum itu dinyatakan oleh

\footnotetext{
${ }^{32}$ Hasil wawancara informan III, ( wawancara dilaksanakan pada 1 mei 2019).

${ }^{33}$ Hasil wawancara informan III, ( wawancara dilaksanakan pada 1 mei 2019).

${ }^{34}$ Hasil wawancara informan III, ( wawancara dilaksanakan pada 1 mei 2019).
} 
informan sebagai suatu persepsi parsial, tidak menyeluruh dan hanya berdasarkan pada kasus-kasus tertentu. Hal tersebut sebagaimana yang disampaikan oleh informan sebagai berikut:

"Alhamdulillah saya mudah bergaul dengan orang lain. Tidak ada yang sulit. Di lingkungan keluarga yang saya lakukan adalah berupaya untuk selalu menampilkan yang terbaik, apalagi keluarga saya, khususnya orangtua belum mendukung saya memakai cadar secara penuh. Otomatis hal yang utama adalah itu tadi, memperbaiki hubungan kepada keluarga agar tetap harmonis. $^{\text {'35 }}$

Pakar sosiologi Soerjono Soekanto menyatakan tentang syarat-syarat terjadinya interaksi sosial ketika salah satu ciri dari interaksi sosial terpenuhi, yakni setiap orang yang terlibat dalam interaksi tersebut memiliki tujuan-tujuan tertentu yang bisa sama dan bisa pula berbeda. ${ }^{36}$

Juga setidaknya harus memuat dua aspek penting dalam interaksi sosial tersebut yakni kontak social (social contact) dan komunikasi sosial (social communication). Kontak sosial adalah hubungan antara satu orang atau lebih melalui percakapan, dialog dan masing-masing pihak mengerti maksud dan tujuannya. Sedangkan komunikasi sosial adalah suatu proses saling memberikan tafsiran kepada atau dari perilaku pihak lain. Melalui tafsiran pada perilaku pihak lain, maka seseorang mewujudkan perilaku sebagai reaksi terhadap maksud atau peran yang ingin disampaikan oleh pihak lain.

Proses kontak dan komunikasi sosial yang berlangsung dalam kehidupan wanita bercadar dijelaskan sebagaimana pernyataan informan berikut ini: ${ }^{37}$

"Selama ini saya menjalankan kontak sosial dan komunikasi dengan masyarakat sekitar itu sebagaimana orang lain pada umumnya. Kalau ada kebutuhan dan keperluan tentu saja saya harus terlibat dalam komunikasi tersebut dan menjalin hubungan yang lebih erat. Kadang-kadang saya juga merasa tidak enak dan khawatir mereka tetangga tidak mau membantu saya, atau tidak merespon tapi alhamdulillah sejauh ini tidak terjadi seperti itu, kekhwatiran saya saja sepertinya. ${ }^{38}$

\footnotetext{
${ }^{35}$ Hasil wawancara informan III, ( wawancara dilaksanakan pada 1 mei 2019).

${ }^{36}$ Soerjono, Soekanto, Sosiologi (Suatu Pengantar) (Jakarta: PT Raja Grafindo Persada, 2012), h. 45.

${ }^{37}$ Hasil wawancara informan III, (wawancara dilaksanakan pada 1 mei 2019).

${ }^{38}$ Hasil wawancara informan II, (wawancara dilaksanakan pada 1 mei 2019).
} 
Dalam Islam, interaksi sosial disebut dengan istilah hablun minannas (hubungan dengan sesama manusia), pengertiannya juga tidak berbeda dengan pengertian interaksi sosial di atas, yaitu hubungan dengan individu, individu dengan kelompok dan kelompok dengan kelompok. Contohnya, saling sapa, berjabat tangan, silaturrahim, solidaritas sosial, ukhuwah Islamiah dan lain-lain. Interaksi sosial yang dilakukan wania bercadar tidak hanya terjadi di kalangan komunitasnya saja secara internal, akan tetapi juga di luar komunitasnya.

Interaksi sosial adalah hubungan antara individu satu dengan individu lain, individu satu dapat mempengaruhi individu yang lain atau sebaliknya, sehingga terdapat hubungan yang saling timbal balik. Hubungan tersebut dapat terjadi antara individu dengan individu, individu dengan kelompok atau kelompok dengan kelompok. ${ }^{39}$ Interaksi sosial yang dilakukan oleh wanita bercadar juga menunjukkan praktek tingkah laku individu yang satu berusaha mempengaruhi, mengubah, atau memperbaiki tingkah laku individu yang lain, dan sebaliknya. ${ }^{40}$ Hal ini sejalan dengan temuan Mappiare yang berproposisi bahwa dalam diri identitas religius wanita berjilbab (belum bercadar) terdapat konflik dan konsensus, ada tarik-menarik duniawi-ukhrawi dan bermartabat-berkerabat. ${ }^{41}$ Dengan demikian, interaksi sosial wanita bercadar dapat pula dipahami lekat dengan konflik dan konsensus identitas simbolik (religius) yang ditampilkannya, ada rasa bermartabat dan berkerabat dalam upaya mempengaruhi individu lainnya.

Interaksi sosial adalah hubungan timbal balik antara individu dengan individu, kelompok dengan kelompok, individu dengan kelompok atau sebaliknya, dengan adanya nilai dan norma yang berlaku secara sosial, maka hal itu dapat dilakukan dengan baik. Jika tidak adanya kesadaran masing-masing antar individu dengan individu atau individu dengan kelompok, maka proses sosial itu tidak akan dapat berjalan dengan baik, sesuai yang diharapkan dalam kehidupan sehari-hari, tentunya, seseorang tidak lepas dengan berinteraksi atau bertukar pikiran. ${ }^{42}$

Dalam mengkonstruksi atau membangun interaksi sosial yang efektif, tidaklah terlalu sulit dalam kehidupan sosial. Perilaku interaksi sosial yang ditunjukkan oleh wanita bercadar seperti sikap simpati, belajar memahami dan menerima

\footnotetext{
${ }^{39}$ Bimo Walgito, Psikologi Sosial (Yogyakarta: Andi Offset, 2003) hal. 33.

${ }^{40}$ Ary. H. Gunawan, Sosiologi Pendidikan (Jakarta: Rineka Cipta, 2010) hal. 106.

${ }^{41}$ Mappiare-AT, A., Identitas Religius di Balik Jilbab: Perspektif Sosiologi Kritik (Malang: Penerbit Universitas Negeri Malang, 2009), h. 2.

${ }^{42}$ Soerjono, Soekanto, Sosiologi (Suatu Pengantar) (Jakarta: PT Raja Grafindo Persada, 2012), h. 90.
} 
keberadaan orang lain. Tidak merendahkan status sosial, tingkat ekonomi, pendidikan dan keluarganya. Namun, lebih menunjukkan kesederhanaan dan saling menghargai dalam kehidupan sosial. Selain itu, juga aspek lainnya seperti memberi manfaat, saling menghargai dan menghormati siapapun, teman berkomunikasi di dalam lingkungan masyarakat. Juga sikap solidaritas sosial kepada teman, keluarga, dan tetangga yang ditimpa musibah.

\section{KESIMPULAN}

Eksistensi wanita bercadar dalam lingkungan masyarakat secara umum yaitu kaitannya dengan proses interaksi sosial dalam kehidupan sehari-sehari menunjukkan fenomena yang secara normatif sesuai dengan nilai-nilai agama Islam. Opini dan streotipe yang berkembang terhadap wanita bercadar seperti tidak mudah untuk berinteraksi dengan masyarakat umum, bersikap kaku, ekstrim dan fanatik, maka secara realitas di lapangan sangat jauh berbeda sebagaimana yang digambarkan oleh para informan. Pola-pola perilaku dengan mengedepankan nilai-nilai kesopanan dan kesantunan adalah proses asosiatif dan perilaku yang juga dipraktekkan wanita bercadar. Wanita bercadar mampu bersosialisasi dengan tetangga, teman dan kerabat serta tidak mengalami kecanggungan dalam berkomunikasi dan berinteraksi sosial sehari-hari. Masyarakat sekitar tidak merasa terganggu dengan keberadaan wanita bercadar oleh karena pola penyesuaian diri dan membuka diri terhadap lingkungannya. Di sisi lain, sebagian wanita bercadar masih menunjukkan sikap tertutup dan kaku dalam proses interaksi sehari-hari. Akan tetapi, dalam kehidupan sehari-hari, penerimaan secara umum terhadap wanita bercadar lambat laun berubah menjadi sikap empati dan transparan dan mulai tidak menunjukkan sikap penolakan (intoleran). Selain itu, potensi konflik batin rentan terjadi dalam lingkup kehidupan wanita bercadar, mulai dengan memperbaiki hubungan kepada keluarga dan masyarakat agar tetap harmonis sehingga mampu mendapatkan dukungan moril yang kemudian mempermudah akses kehidupan sosialnya.

\section{DAFTAR PUSTAKA}

Al-Qur'an.

Ary, H. Gunawan. (2010). Sosiologi Pendidikan. Jakarta, Rineka Cipta.

Bimo, Walgito. (2003). Psikologi Sosial. Yogyakarta, Andi Offset.

Daud, F. K. (2013). Jilbab, hijab dan aurat perempuan (Antara tafsir klasik, tafsir kontemporer dan pandangan muslim feminis). Al Hikmah: Jurnal Studi Keislaman, 3(1), 1-1. 
Ghonimah, G. (2017). IDENTITAS MAHASISWI BERCADAR DI UNIVERSITAS ISLAM NEGERI SUNAN AMPEL SURABAYA (Doctoral dissertation, UIN Sunan Ampel Surabaya).

Jumaidah, J. (2018). Problematika pemakaian cadar di Universitas Islam Negeri (UIN) Walisongo Semarang (Doctoral dissertation, UIN Walisongo Semarang).

Mappiare-AT, A. (2009). Identitas Religius di Balik Jilbab: Perspektif Sosiologi Kritik. Malang: Penerbit Universitas Negeri Malang.

Mappiare, A. (2009). Dasar-dasar Metodologi Riset Kualitatif Untuk Ilmu Sosial dan Profesi. Malang: Jenggala Pustaka Utama Bersama Fakultas Ilmu Pendidikan Universitas Negeri Malang.

Mappiare, A. (2013). Tipe-tipe Metode Riset Kualitatif Untuk Eksplanasi Sosial Budaya dan Bimbingan Konseling. Malang: Elang Mas bersama Prodi Bimbingan dan Konseling Fakultas Ilmu Pendidikan Universitas Negeri Malang.

Prasetyo. "Pengertian Cadar" dalam http://repository.uma.ac.id/bitstream/123456789/2052/5/128600060_file5 .pdf/ diakses pada 1 mei 2019.

Rahman, A. F., \& Syafiq, M. (2017). Motivasi, stigma dan coping stigma pada perempuan bercadar. Jurnal Psikologi Teori dan Terapan, 7(2), 103-115.

Ratri, L. (2011). Cadar, Media, dan Identitas Perempuan Muslim. In Forum(Vol. 39, No. 2, pp. 29-37).

Rudianto. (2006). “Jilbab sebagai Kreasi Budaya (Studi Kritis Ayat - ayat Jilbab dalam Al-Qur'an).Medan, IAIN PRESS.

Soerjono, Soekanto. (2012). Sosiologi (Suatu Pengantar). Jakarta, PT Raja Grafindo Persada.

Shihab, M. Quraish. (2004). Jilbab: Pakaian Wanita Muslimah (Pandangan Ulama Masa Lalu dan Cendekiawan Kontemporer). Jakarta, Lentera Hati.

Taimiyah, dkk. (2010). Hijab dan Cadar bagi Wanita Muslimah. Yogyakarta, At Tuqa.

Zeitlin, Irving M. (1995). Memahami Kembali Sosiologi. Yogyakarta, Gadjah Mada University Press. 